\title{
Study on the Necessity of Establishing the Name Right of New Varieties of Plants Law
}

\section{Yangkun Hou*}

Doctor of Intellectual Property Law, School of Law, Beijing Institute of Technology, China

\begin{abstract}
In the new plant variety rights, there is no special name right. In fact, in the various types of violations of new varieties of plants, violations of the name of new varieties of plants is the main form of infringement. Therefore, in the new plant variety rights, the establishment of a special name right is very necessary.
\end{abstract}

Keywords: Plants law; Plant variety rights; Infringement; Special legal provisions; Taxonomic provisions; Breeding techniques

\section{Introduction}

At present, in the world, in addition to the United States set up a special plant patent law, other countries are the use of new plant variety rights to protect the new varieties of plant. However, in the existing plant variety rights, the lack of the special provisions on protection of the name of new species of plant. In the process of production and sale of new varieties of plants, many illegal personnel use the counterfeit name of plants to implement the infringement in order to obtain high illegal income. Therefore, in order to effectively protect the new varieties of plants, should establish the special legal provisions for the protection of the names of new varieties of plants [1].

\section{The Meanings and Basic Characteristics of New Varieties of Plant}

The difference and linkage between plant varieties and new varieties of plant

In terms of range, plant varieties include both of new varieties of plant and non-plant new varieties, so the new varieties of plant are part of the plant varieties. This relationship can be represented by the following diagram: (Figure 1).

\section{Classification and cultivation of plants}

According to taxonomic provisions, classification of the order from high to low as follows:

Kingdom, Phylum, Class, Order, Family, Genus, and Species for plant classification, under the species, under normal circumstances is divided into the following three categories: Subspecies, Variety and Form [2].

The above is the classification of taxonomy. The main basis of classification is the external morphological characteristics of plants and

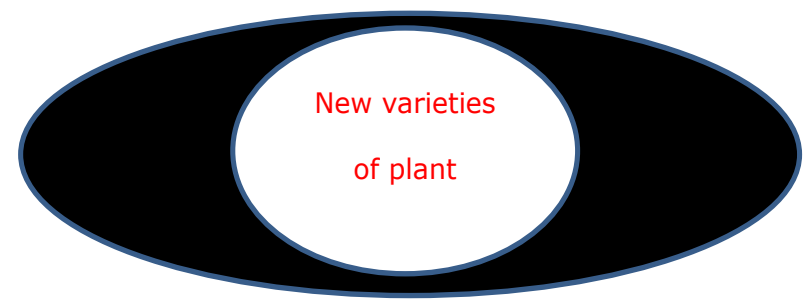

Figure 1: This relationship between the new varieties of plant is part of the plant varieties. the geographical distribution characteristics. In agriculture, gardens and forage production, in addition to the above plant classification, there is also a concept called "cultivar".

From the classification level, the cultivars correspond to Subspecies, Variety and Form. In the range, cultivars contain Subspecies, Variety and Forms, but do not contain all of them. Only those parts that are useful in agriculture, gardens and pasture production can belong to cultivars [3].

The difference and linkage between plants varieties and cultivated varieties

In terms of range, plant varieties contain cultivars, so it can be said that all cultivars are plant varieties, but not all plant varieties belong to cultivars.

\section{The difference and linkage between new varieties of plant and cultivars}

From the scope of speaking, only a part of the new varieties of plants are cultivated varieties, and only part of the cultivars are new varieties of plants [4].

The basic meanings and characteristics of new varieties of plants

The new plant variety is a concept related to plant classification. At the classification level, under the kind of species, corresponding to Subspecies, Variety and Forms, but also with them are different; this difference is mainly divided by their different standards. The criteria for dividing Subspecies, Variety and Form are mainly their external morphological characteristics and geographical distribution, but the criteria for dividing new varieties of plants include external morphological characteristics, internal physiological and biochemical indicators and agricultural production indicators [5].

In addition, Subspecies, Variety and Form are conceptual in

*Corresponding author: Hou Y, Doctor of Intellectual Property Law, School of Law, Beijing Institute of Technology, China, Tel: 86-10-68915173; E-mail: hykpost@263.net

Received February 10, 2017; Accepted March 15, 2017; Published March 23, 2017

Citation: Hou Y (2017) Study on the Necessity of Establishing the Name Right of New Varieties of Plants Law. Intel Prop Rights. 5: 183. doi: 10.4172/23754516.1000183

Copyright: (c) 2017 Hou Y. This is an open-access article distributed under the terms of the Creative Commons Attribution License, which permits unrestricted use, distribution, and reproduction in any medium, provided the original author and source are credited. 
taxonomy, and the review and confirmation of a Subspecies, Variety or Form is entirely based on a taxonomic procedure.

Cultivar is a concept of agricultural production, and the review and confirmation of a cultivar is entirely a matter for the formulation of agricultural management.

The new varieties of plants are a legal concept, and the review and confirmation of a new varieties of plants is based solely on the provisions of the New Varieties of Plant Protection Law.

\section{The Name of New Varieties of Plants is an Important Part of the New Varieties of Plants}

According to the Convention on the Protection of New Varieties of Plants (UPOV), new varieties of plants that apply for new plant variety rights must have approved a name of new variety of plant, otherwise the new varieties of plants rights cannot be granted.

Obviously, in UPOV, the names of the new varieties of plants are only one of the conditions for granting the varieties rights and the other four conditions are novelty, uniqueness, stability and consistency.

The UPOV Convention now has three different texts, namely the 1961 text, the 1978 text and the 1991 text. In these three texts, the variety rights contains different contents, from 1961 to 1978, and from 1978 text to the 1991 text, variety rights in the scope of protection and protection efforts are increasing and strengthening. However, in the content of the three texts, there has been no provision to specifically protect the name of the new varieties of plants.

In the existing UPOV convention, the role of the name of the new varieties of plants is only used to determine the presence of new varieties of plants, as well as to distinguish between other new varieties of plants.

In fact, in addition to the above functions, in the seed production and sales, the name of the new varieties of plants has been still playing other more important roles, and these effects are part of the roles of new varieties of plants, with new varieties of plants cannot be separated.

It is only that in the existing UPOV convention has not set up specific provisions on these important roles, and it is clear that the emergence of this situation is a legislative lack and imperfect, we should amend and remedy UPOV convention as soon as possible [6].

\section{The Main Way to Implement the Infringement by Using Name of the New Varieties of Plants}

Through many years of the survey conducted in the Chinese market, it has been found that there are several types of infringing acts using the name of the new plant variety:

\section{Directly counterfeit the name of the new varieties of plants which has been granted}

The basic characteristics of such violations are using other names of plant varieties to impersonate the names of new varieties of plants that have been authorized

Here the "other names of plant varieties" may be the real name of the plant varieties, it may be completely fictitious names of plant varieties. This way of infringement not only occurs in large numbers in social reality, but also it is the main types of infringement using the names of new varieties of plants. The prerequisite for such violations is that the sale of this new variety of plants is better and has been welcomed by farmers. Another reason for this type of infringement is that the seeds of different plant species are basically similar in shape, and in many cases it is difficult for farmers to discover and identify such counterfeit behavior on their own eyes and knowledge. The infringer implements such infringement, can use the unauthorized varieties of plants to counterfeit already authorized new varieties of plants, can also use another new varieties of plants that has been authorized but sold poorly to counterfeit other new varieties of plant which has been selling well.

The infringer who conducts such infringement is primarily a person other than breeder, but in some cases breeder may commit such infringement.

Other than the breeders uses "other names of plant varieties" to counterfeit the names of new varieties of plants that have been authorized: For example, an authorized new varieties of plants, its name is $\mathrm{AA}$, its breeder is AA- 1 . The other person is $\mathrm{BB}-2$, the name of his plant variety is $B B$, when $B B-2$ wants to produce and sell $B B$, he marks $\mathrm{BB}$ as $\mathrm{AA}$, it is using the $\mathrm{BB}$ counterfeit $\mathrm{AA}$.

Breeders uses "other names of plant varieties" to counterfeit the authorized new varieties of plants: Some owners of new varieties of plants, in order to obtain higher returns, It is also possible to use other plant varieties to impersonate new varieties of plants that have been authorized for their own. The prerequisites for such infringement are generally owners own new varieties of plants are not very good, they have been ready to produce another varieties of plants used to replace, but the existing new varieties of plants have a certain sales market, in this case, breeders may use similar other varieties of plants to impersonate this new varieties of plants for production and sale.

There is also a situation where the breeder has a number of new varieties of plants that have been authorized, but only one of them is best sold, in this case, the breeder may use other new varieties of plants to fake such best one for sale.

\section{Indirectly counterfeit the name of the new varieties of plants which has been granted}

At present, many infringers in order to escape the direct infringement of the legal responsibility, has begun to use advanced breeding techniques, especially genetically modified breeding technology, has begun to implement indirect infringement.

The basic characteristics of this type of indirect infringement are the use of other breeder's new varieties of plants which have been authorized and sold well as parent, and then conducts some simple genetic treatment of the parent, altering a small number of unimportant genes, retaining the primary characteristics of the parent, so quickly obtain another new varieties of plants. Then use these new varieties of plants to apply for and obtain their own new varieties of plants rights, and then use this legitimate right to produce and sell their new varieties of plants.

Now, in the Chinese market, such infringement more and more, some seed industry companies to implement such violations, some breeding scientific research units to use their own technological advantages are also involved in such violations. An important reason for the occurrence of such violations is that there is no clear provision and prohibition on such false breed in legislation.

Preventing and combating such infringement can be done from the perspective of false labeling of new varieties of plants names, because in essence, this infringement is only the use of legislation loopholes. 
Citation: Hou Y (2017) Study on the Necessity of Establishing the Name Right of New Varieties of Plants Law. Intel Prop Rights. 5: 183. doi: 10.4172/2375-4516.1000183

Page 3 of 3

Here, if the original new varieties of plants called AA, after a simple gene treatment of $\mathrm{AA}$, the new varieties of plants obtained by the known as BB, because the two new varieties of plants are no different characteristics, in fact, should belong to the same new varieties of plants, so both of them are actually new varieties of plants AA. Where the $\mathrm{BB}$ is a false name, it is the impersonation of $\mathrm{AA}$

\section{Counterfeit other plant varieties names by using the names of authorized new varieties of plants}

Some of the new varieties of plants that have been authorized to be sold in the market are not ideal and cannot be recognized and welcomed by farmers. In this case, the person who has produced and sell these new varieties of plants may use these new varieties of plants to counterfeit other new varieties of plants which have a good sales. The counterfeit plant variety may be just one, also may be more; it may be an authorized new varieties of plants, also may be a unauthorized one.

In order to obtain better returns, breeders may also enforce such infringement in some cases.

\section{Design and Legislative Proposals for the Name Rights of New Varieties of Plants}

\section{The basic contents should be included in the name rights of new varieties of plants}

From the above discussion, it can be seen that the infringement of the name of the new varieties of plants includes acts of counterfeiting by other plant varieties and the behavior of counterfeiting other plant varieties; among which the acts of counterfeiting by other plant varieties include the direct fake acts, and indirect acts of counterfeiting.

In order to stop and combat these three types of tort, therefore, in the name of the new varieties of plants should be designed three basic rights, specifically to stop these three types of violations.
Exclusive use rights of the name of new varieties of plants: The owners of new varieties of plants have exclusive rights to this new varieties of plants, and without the permission of the owners, no one can make the name of this new plant variety, or a name similar to this name, to be used by other plant varieties.

No one can for commercial purposes, use this name or similar name on other goods or services.

The right to prevent being illegally replaced: New varieties of plants owners have the right to prohibit any person from using various means, with other plant varieties to replace this new plant variety.

\section{Conclusion}

In the existing law of protecting new varieties of plants, due to the lack of special contents to protect the names of new varieties of plants, it is difficult for the right holders to effectively protect their rights and the legitimate interests that should be obtained, this is a clear loophole in the legislation, the legal deficiencies should be amended and remedied as soon as possible.

\section{References}

1. Helfer LR (2004) Intellectual property rights in plant varieties, International legal regimes and policy options for national governments, Food and Agriculture Organization of the United Nations, Rome.

2. Sneath PH, Sokal RR (1973) Numerical taxonomy. The principles and practice of numerical classification.

3. Plant variety rights (2015). intellectual property (IP), New Zealand.

4. Getting the Most out of your New Plant Variety (2016) The World Intellectual Property Organization. Patent Cooperation Treaty, Madrid and Hague Systems, Switzerland.

5. Classification of Crop Plants (2015) My agricultural information bank, India.

6. Sullivan B (2016) Henry Hughes Patent \& Trademark Attorneys, New Zealand 